\title{
Environmental impacts of shipping in 2030 with a particular focus on the Arctic region
}

\author{
S. B. Dalsøren ${ }^{1}$, B. H. Samset ${ }^{1}$, G. Myhre ${ }^{1}$, J. J. Corbett ${ }^{2}$, R. Minjares ${ }^{3}$, D. Lack ${ }^{4,5}$, and J. S. Fuglestvedt ${ }^{1}$ \\ ${ }^{1}$ CICERO, Center for International Climate and Environmental Research Oslo, Norway \\ ${ }^{2}$ College of Earth, Ocean, and Atmosphere, University of Delaware, Newark, USA \\ ${ }^{3}$ The International Council on Clean Transportation, San Francisco, USA \\ ${ }^{4}$ NOAA Earth System Research Laboratory, Chemical Sciences Division, Boulder, USA \\ ${ }^{5}$ Cooperative Institute for Research in Environmental Sciences, University of Colorado, Boulder, USA
}

Correspondence to: S. B. Dalsøren (stigbd@cicero.oslo.no)

Received: 13 July 2012 - Published in Atmos. Chem. Phys. Discuss.: 9 October 2012

Revised: 25 January 2013 - Accepted: 6 February 2013 - Published: 20 February 2013

\begin{abstract}
We quantify the concentrations changes and Radiative Forcing (RF) of short-lived atmospheric pollutants due to shipping emissions of $\mathrm{NO}_{\mathrm{x}}, \mathrm{SO}_{\mathrm{x}}, \mathrm{CO}, \mathrm{NMVOCs}, \mathrm{BC}$ and OC. We use high resolution ship emission inventories for the Arctic that are more suitable for regional scale evaluation than those used in former studies. A chemical transport model and a RF model are used to evaluate the time period 2004-2030, when we expect increasing traffic in the Arctic region. Two datasets for ship emissions are used that characterize the potential impact from shipping and the degree to which shipping controls may mitigate impacts: a high (HIGH) scenario and a low scenario with Maximum Feasible Reduction (MFR) of black carbon in the Arctic. In MFR, BC emissions in the Arctic are reduced with $70 \%$ representing a combination technology performance and/or reasonable advances in single-technology performance. Both scenarios result in moderate to substantial increases in concentrations of pollutants both globally and in the Arctic. Exceptions are black carbon in the MFR scenario, and sulfur species and organic carbon in both scenarios due to the future phasein of current regulation that reduces fuel sulfur content. In the season with potential transit traffic through the Arctic in 2030 we find increased concentrations of all pollutants in large parts of the Arctic. Net global RFs from 2004-2030 of $53 \mathrm{~mW} \mathrm{~m}^{-2}$ (HIGH) and $73 \mathrm{~mW} \mathrm{~m}^{-2}$ (MFR) are similar to those found for preindustrial to present net global aircraft RF. The found warming contrasts with the cooling from historical ship emissions. The reason for this difference and the higher global forcing for the MFR scenario is mainly the re-
\end{abstract}

duced future fuel sulfur content resulting in less cooling from sulfate aerosols. The Arctic RF is largest in the HIGH scenario. In the HIGH scenario ozone dominates the RF during the transit season (August-October). RF due to BC in air, and snow and ice becomes significant during Arctic spring. For the HIGH scenario the net Arctic RF during spring is 5 times higher than in winter.

\section{Introduction}

Observations over the past $50 \mathrm{yr}$ show a decline in Arctic seaice extent throughout the year, with fastest retreat in summer (Serreze et al., 2007; Lemke et al., 2007; Stroeve et al., 2012a, b). Less sea-ice cover and reduced ice thickness implies improved access for shipping around the margins of the Arctic Basin. Climate models project an acceleration of the ice melting leaving the Arctic Ocean increasingly open to shipping (Meehl et al., 2007; Stroeve et al., 2012a). In the next decades melting of sea ice may open entirely new possibilities with respect to new shipping routes in the Arctic (Stephenson et al., 2011; Arctic Council, 2009). Studies are examining the implications of emergent new shipping routes and extension of the period during which shipping is feasible (Corbett et al., 2010a; Paxian et al., 2010; Peters et al., 2011). Unless measures are taken increases in emissions are expected (Corbett et al., 2010a).

The current impact of Arctic shipping on pollutant levels and climate is discussed in Ødemark et al. (2012) and can 
also be interpreted from several studies with more global focus (Dalsøren et al., 2009; Eyring et al., 2007, 2010; Hoor et al., 2009). Mölders et al. (2010) calculate the impact on air quality in Alaska and find large contributions to $\mathrm{NO}_{\mathrm{x}}$ deposition and PM concentrations and significant impact on other pollutants. In this study we use high resolution ship emission inventories for the Arctic more suitable for regional scale evaluation than those used in former studies. Some model studies have been done on impacts of future ship emissions in the Arctic but these are mainly made for parts of the region or based on simplified or old projections. In a prior study Dalsøren et al. (2007) focused on expected increased oil and gas transport by ships from Norway and Northwest Russia, and sea transport along the Northern Sea Route. They found significant regional effects by increases of acid deposition in the North Scandinavia and the Kola Peninsula. Augmented levels of particles over much of the Arctic were also calculated. Granier et al. (2006) studied the potential increases in ozone pollution using one of the upper emission estimates for 2050 from Eyring et al. (2005) and introduced a scenario where shipping activity grows with an increase in ice-free Arctic waters. During the summer months, surface ozone concentrations in the Arctic could be enhanced by a factor of 2-3 as a consequence of ship operations through the northern passages. Projected ozone concentrations from July to September were comparable to summertime values currently observed in many industrialized regions in the Northern Hemisphere.

Ship emissions are projected to increase significantly also outside Arctic waters due to increases in transportation demand and traffic (Eyring et al., 2005; Paxian et al., 2010; Buhaug et al., 2009; Eide, 2007). Most scenarios for the next $10-20 \mathrm{yr}$ indicate that efficiency improvements and emission controls due to current regulatory policies could be outweighed by an increase in traffic resulting in a global increase in emissions. Of course, policy-induced controls are very dependent on the success of adapted and proposed regulations within the International Maritime Organization (IMO) and other regulatory bodies (Eyring et al., 2010; Buhaug et al., 2009). Results for future global impacts from ship emissions are therefore dependent on the projections used as baseline for the emission calculations. Cofala et al. (2007) find that the contribution from shipping to sulfur deposition in European coastal areas is expected to increase by 2020 to more than $30 \%$ in large areas, and up to $50 \%$ in coastal areas. The impacts of possible near future sulfur regulations on health and climate were quantified by Lauer et al. (2009) and Winebrake et al. (2009). Technologies exist to reduce emissions from ships beyond what is currently legally required. Cofala et al. (2007) also performed a cost-effectiveness analysis for several possible sets of measures. Eyring et al. (2007) used results from ten state-of-the-art atmospheric chemistry models to analyse present-day conditions (year 2000) and two future ship emission scenarios. In one scenario ship emissions stabilize at 2000 levels, in the other ship emissions increase with a constant annual growth rate of $2.2 \%$ up to 2030. Future evolution of climate metrics and temperature due to several international shipping scenarios are discussed in Fuglestvedt et al. (2009), Skeie et al. (2009) and Lund et al. (2012).

Corbett et al. (2010a) presents a number of scenarios for ship emissions and routes in the Arctic in 2030 and 2050 as well as estimates for total emission changes in the ship fleet operating in the rest of the world. In this study we apply their high and low scenario for 2030 in atmospheric models to investigate the imposed effects on pollution levels and climate. The applied emission scenarios are presented in Sect. 2. In Sect. 3 we describe the models and setup of our studies. Section 4 is devoted to the impacts on pollution (atmospheric composition) and climate (radiative forcing). We focus on short-lived components which we define as primary or secondary products with lifetimes shorter than the longest timescale for mixing in the troposphere, i.e. 1-2 yr for interhemispheric mixing. Section 5 discusses the results and treats uncertainties, while the major findings are summarized and set into a perspective in Sect. 6 .

\section{Emission scenarios}

Corbett et al. (2010a) provides gridded inventories for current (2004) and future $(2030,2050)$ ship emissions of greenhouse gases and gas and particulate pollutants in the Arctic. That study presents several options for emission totals and diversion routes through the Arctic in 2030. In this study we compare their highest and lowest estimates to get an impression of the range of possible future effects due to emissions of $\mathrm{NO}_{\mathrm{x}}, \mathrm{SO}_{\mathrm{x}}, \mathrm{CO}$, NMVOCs, $\mathrm{BC}$ and OC. Table 1a compares the yearly total Arctic ship emissions for some of these components, for 2004 and for our two 2030 scenarios.

In the high growth scenario (HIGH) there is more than a doubling in energy use for shipping serving the Arctic. In addition $2 \%$ of the global traffic diverts to Arctic throughroutes. Global shipping growth outside the Arctic is $+3.3 \%$ per year on average, and most uncontrolled emissions grow proportionally to shipping activity. For some pollutants there are exceptions; $\mathrm{SO}_{\mathrm{x}}$ and $\mathrm{NO}_{\mathrm{x}}$ follow new IMO regulations to be implemented by 2020 and OC is correlated with changes in $\mathrm{SO}_{\mathrm{x}}$ emissions (Lack et al., 2009). Large emission increases (factors of 2 to 5) are found (Table 1a) for all species except sulfur where regulations on sulfur content outweigh the increase in fuel consumption. The emissions from diversion traffic are larger than those from the fleet operating solely within the Arctic.

In the MFR scenario a business as usual scenario is followed but maximum feasible reduction is applied on Arctic BC emissions (also affecting OC), representing more aggressive emission controls than current policies. The assumptions are based on combined technology performance and/or reasonable advances in single-technology 
Table 1a. Ship emissions north of $60^{\circ} \mathrm{N}$ in 2004 and 2030 $\left(\mathrm{Kton}^{-1}{ }^{-1}\right.$ ) from Corbett et al. (2010a). There is seasonal variation in the emissions from the Arctic fleet. The diversion fleet operates in the period August-October. Numbers in bold are total emission each year, numbers in normal font are emissions for the sections of the total fleet.

\begin{tabular}{lrrrr}
\hline & $\mathrm{NO}_{\mathrm{x}}$ & $\mathrm{SO}_{2}$ & $\mathrm{BC}$ & $\mathrm{OC}$ \\
\hline $\mathbf{2 0 0 4}$ & $\mathbf{1 9 6}$ & $\mathbf{1 3 6}$ & $\mathbf{0 . 8 8}$ & $\mathbf{2 . 7 0}$ \\
2030 HIGH & $\mathbf{7 3 9}$ & $\mathbf{1 3 0}$ & $\mathbf{4 . 5 0}$ & $\mathbf{5 . 1 0}$ \\
Arctic fleet & 329 & 58 & 2.00 & 2.30 \\
Diversion fleet & 410 & 72 & 2.50 & 2.80 \\
2030 MFR & $\mathbf{3 8 4}$ & $\mathbf{6 8}$ & $\mathbf{0 . 7 6}$ & $\mathbf{0 . 8 4}$ \\
Arctic fleet & 244 & 43 & 0.46 & 0.51 \\
Diversion fleet & 140 & 25 & 0.30 & 0.33 \\
\hline
\end{tabular}

Table 1b. Non-Arctic ship emissions in 2004 and $2030\left(\mathrm{Kton}_{\mathrm{yr}}{ }^{-1}\right)$. The non-Arctic ship traffic distribution and emissions for 2004 are from Dalsøren et al. (2009). The 2030 emission scenarios are based on Corbett et al. (2010a). There is seasonal variation in the emissions.

\begin{tabular}{lrrrr}
\hline & $\mathrm{NO}_{\mathrm{x}}$ & $\mathrm{SO}_{2}$ & $\mathrm{BC}$ & $\mathrm{OC}$ \\
\hline 2004 & 15187 & 8699 & 35 & 120 \\
$2030 \mathrm{HIGH}$ & 24854 & 3672 & 80 & 97 \\
$2030 \mathrm{MFR}$ & 18063 & 2668 & 58 & 73 \\
\hline
\end{tabular}

performance. Technologies for reducing $\mathrm{BC}$ emissions are discussed briefly in Corbett et al. (2010a) and in detail in Corbett et al. (2010b). $1 \%$ of the global traffic diverts to Arctic through-routes, and global shipping growth outside the Arctic is $+2.1 \%$ per year. $\mathrm{SO}_{\mathrm{x}}$ and $\mathrm{NO}_{\mathrm{x}}$ reductions follow IMO regulations and $\mathrm{OC}$ is correlated with $\mathrm{SO}_{\mathrm{x}}$, unless additionally reduced by MFR controls. For the 2030 MFR scenario $\mathrm{NO}_{\mathrm{x}}$ emissions in the Arctic (Table 1a) are doubled, but MFR controls reduce $\mathrm{BC}$ by some $70 \%$, sulfur emissions are halved, and $\mathrm{OC}$ which is correlated both with sulfur and $\mathrm{BC}$ is about one third. With these scenario conditions, yearly total emissions for regional traffic in MFR are factors 1.5 to 1.7 larger than for the diversion traffic.

Large seasonal variations described by Corbett et al. (2010a) are embedded in the yearly total Arctic shipping emissions in Table 1a. Emissions are dominated by summer and fall activity. For 2004 winter (December-February) and spring (March-May) emissions are 30\% lower than the other seasons. For 2030 the seasonal differences are even larger due to the diversion traffic operating only in 3 months (August-October). Following the recommendations from Corbett et al. (2010a) Table 12, we assume that traffic in 2030 in diversion routes follows the coasts, passing through the Northeast Passage and Northwest Passage. We have not imposed traffic over the pole as that route may not become available until after 2050 (Corbett et al., 2010a).
In order to get global gridded ship emissions we complement the Arctic inventories from Corbett et al. (2010a) with those for 2004 from Dalsøren et al. (2009). The Arctic inventory covers the AMAP region and the Dalsøren et al. (2009) dataset elsewhere. For definition of the AMAP region see Peters et al. (2011). This definition is used to easily compare this study with the results from a separate ongoing study (Dalsøren et al., 2013) using the 2030 and 2050 Arctic ship emissions from Peters et al. (2011). For the nonArctic developments from 2004 to 2030 are obtained assuming changes in emission totals in accordance with Corbett et al. (2010a) $(+3.3 \%$ per year in HIGH, $+2.1 \%$ per year in MFR). The non-Arctic ship emissions are shown in Table $1 b$. As in the Arctic scenarios, $\mathrm{SO}_{\mathrm{x}}$ and $\mathrm{NO}_{\mathrm{x}}$ follow IMO regulations, while $\mathrm{OC}$ is correlated with changes in $\mathrm{SO}_{\mathrm{x}}$ emissions. Uniform scaling is used from 2004 to 2030 assuming no changes of the trade routes outside the Arctic.

For all model simulations we used the Edgar 3.2 inventory (Olivier et al., 2005) for non-ship anthropogenic emissions and the RETRO inventory (Schultz et al., 2007) for natural emissions. No changes were made in these emissions between the model simulations for 2004 and 2030.

\section{Model and methods}

To calculate the impacts on pollution and chemical composition the OsloCTM2 model was used. Simulations were performed in T42 resolution $\left(2.8^{\circ} \times 2.8^{\circ}\right)$ with 60 vertical layers using meteorological data for 2006 . The tropospheric distributions of 137 chemical species are calculated, amongst them hydrogen, oxygen, nitrogen, and carbon containing gases and also sulfate, nitrate, primary organic, secondary organic, black carbon (BC), and sea salt aerosols. The gas and aerosol schemes are described in (Myhre et al., 2009; Skeie et al., 2011a, b; Berglen et al., 2004; Ødemark et al., 2012; Hoyle et al., 2007). OsloCTM2 modeled distributions of ozone and ozone precursors in coastal regions were evaluated and compared to observations in some former ship impact studies (Endresen et al., 2003; Dalsøren et al., 2007, 2010). The model results corresponded with those of other models in a model assessment of ship impact (Eyring et al., 2007). A basis simulation was performed for 2004 and then runs were done with the $2030 \mathrm{HIGH}$ and MFR ship emission scenarios. Meteorology and emissions from all other sectors were kept identical in the three simulations. All simulations had 5 months of spin-up starting with the same initial conditions.

The tropospheric distributions of greenhouse gases and aerosols were fed into a radiative forcing model (Myhre et al., 2009) to calculate the climate impact of the changes in ship emissions from 2004 to 2030 . This model is based on the DISORT radiative transfer scheme (Stamnes et al., 1988), and uses eight multiple scattering streams and four shortwave spectral bands. For $\mathrm{O}_{3}$ forcing calculations, a broadband 

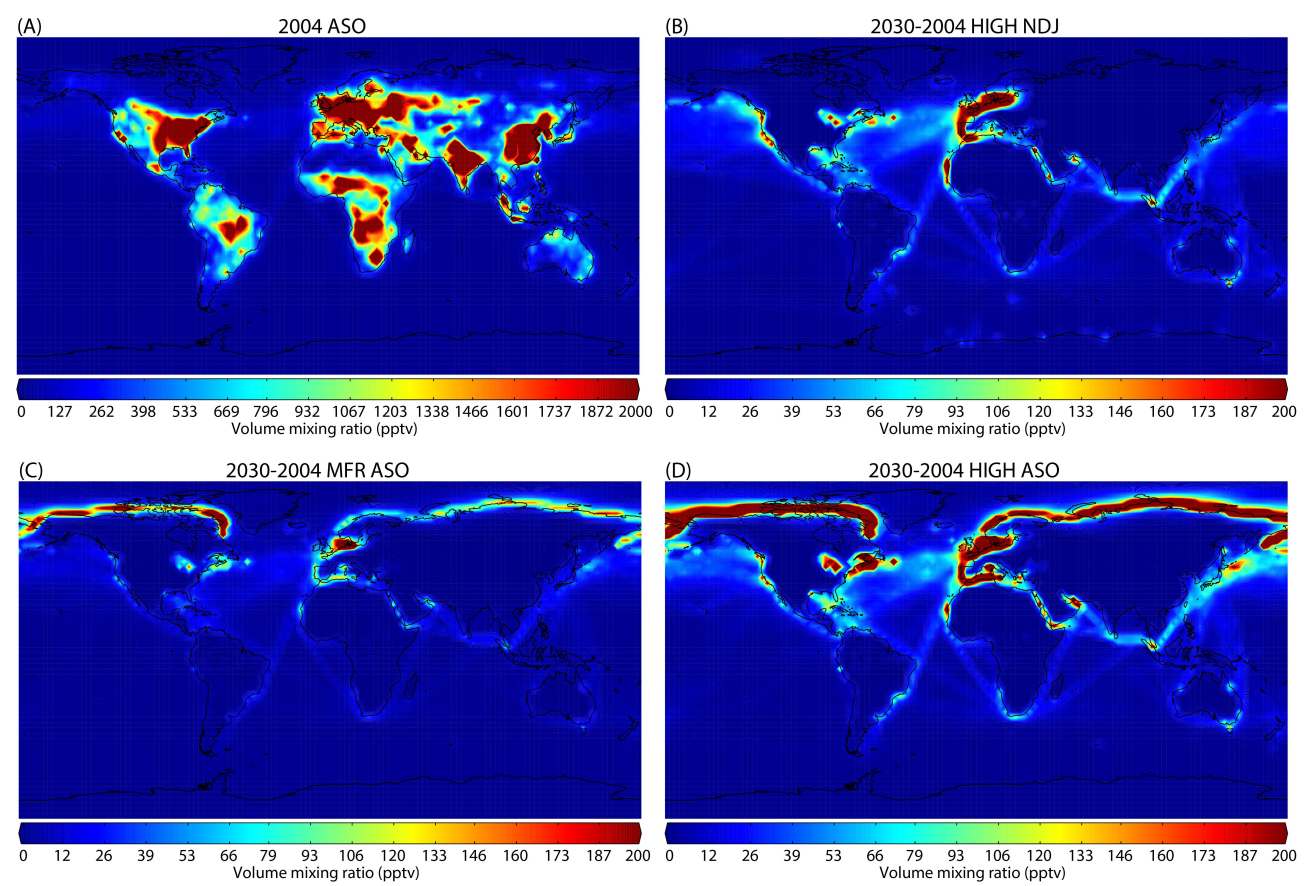

Fig. 1. $\mathrm{NO}_{2}$ in the lowest model layer close to the surface (pptv). (A) Average 2004 for the months August-September-October (ASO). (B) Average change 2004-2030 for HIGH scenario for the months November-December-January (NDJ). (C) Same as (B), MFR scenario, months ASO. (D) Same as (B), HIGH scenario, months ASO.

thermal infrared scheme is also implemented (Myhre et al., 2011). Temporal and spatial resolutions were the same as for OsloCTM2 for aerosols, whereas monthly mean data were used for ozone. The optical properties of aerosols in the model are discussed in Myhre et al. (2007). Direct radiative forcing was calculated as the difference in top-of-atmosphere energy flux between a simulation with all components at 2030 levels, and one that has one component changed to 2004 levels. Stratospheric temperature adjustment was included in the calculations for ozone changes. Standard backgrounds of other aerosols were always present in the calculations. A similar scheme was used for calculating the effects of BC deposition on snow (Skeie et al., 2011a). The first indirect aerosol (cloud albedo) effect was calculated by estimating cloud droplet number from an empirical relationship with aerosol concentration (Quaas and Boucher, 2005; Quaas et al., 2006), and calculating the difference between aerosols at 2030 and 2004 levels as for the direct aerosol effect. See Ødemark et al. (2012) for details.

\section{Results}

To illustrate the large dependency of atmospheric impacts on seasonality in emissions and meteorology results are shown as seasonal means. Averages are made for the four seasons NDJ (November-December-January), FMA (FebruaryMarch-April), MJJ (May-June-July) and ASO (August-
September-October, i.e., the period with Arctic transit traffic in 2030).

\subsection{Changes in pollution and chemical composition}

Figure 1 shows the average ASO surface distribution of $\mathrm{NO}_{2}$ in 2004 as well as absolute changes in 2030 due to the HIGH and MFR ship scenarios. In 2004 the highest $\mathrm{NO}_{2}$ concentrations are found over industrialized regions, megacities and areas with frequent vegetation fires. In both future scenarios the $\mathrm{NO}_{2}$ changes are close to or within the shipping lanes, due to the short atmospheric lifetime of this gas. For the MFR scenario increases are typically $10-80$ pptv $(10-40 \%$ relative to 2004) outside Arctic waters, with larger absolute increases in the highly trafficked English Channel and North Sea. In the Arctic similar perturbations are found in regions with internal Arctic traffic, for instance around Iceland. The diversion routes are more clearly visible, exhibiting increases from 80 to 200 pptv (above $200 \%$ in pristine regions). In the HIGH scenario there are large increases, up to hundreds of pptv, in the Arctic (above $200 \%$ ) for the ASO season, but much smaller changes in NDJ when ice conditions prevent trade route diversion and allow less internal traffic. The changes in coastal regions in the Norhern Hemisphere are substantial, from 60 to above $200 \mathrm{pptv}(20-60 \%)$. In the Southern Hemisphere the increases in major shipping lanes are typically $20-50$ pptv (20-60\%). 

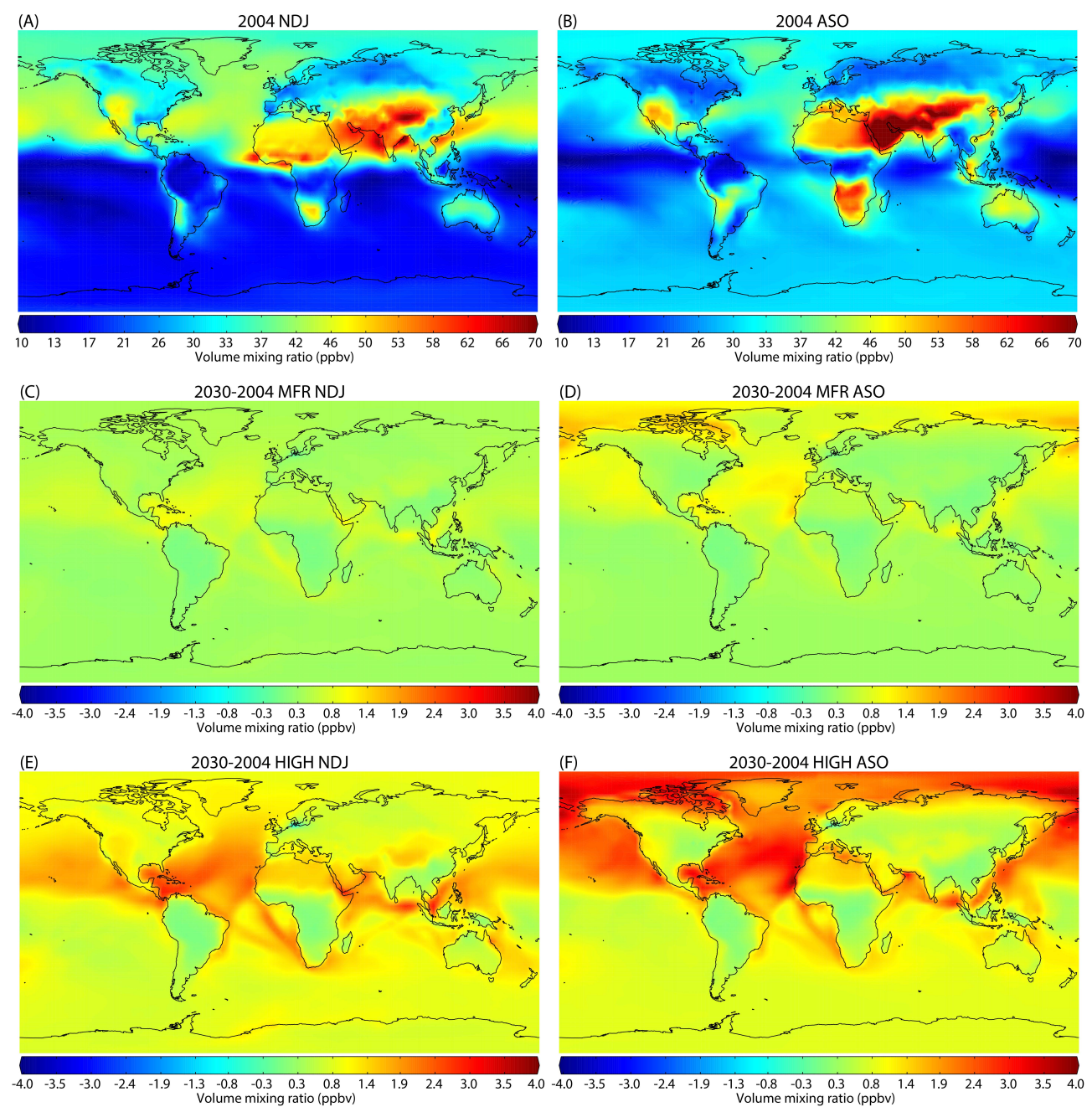

Fig. 2. $\mathrm{O}_{3}$ in the lowest model layer close to the surface (ppbv). Averages 2004 for the months November-December-January (NDJ) (A) and August-September-October (ASO) (B). Average change 2004-2030 MFR scenario for the months NDJ (C) and ASO (D). Average Change 2004-2030 HIGH scenario for the months NDJ (E) and ASO (F).

The year 2004 ASO and NDJ distributions of surface ozone are shown in Fig. 2. High levels are found downwind of polluted regions with extended periods of sunlight and favorable conditions for ozone formation, especially over oceans and deserts where dry deposition is slow. The changes in the MFR scenario are moderate, a few ppbv/percent over the oceans and coastal areas. Except for the ASO season small changes are found in the Arctic region. This is expected since the $\mathrm{NO}_{\mathrm{x}}$ emissions from traffic within the Arctic are only slightly larger than in 2004. Since ship emissions of other ozone precursors (VOCs, $\mathrm{CO}$ ) are small, $\mathrm{NO}_{\mathrm{x}}$ $\left(\mathrm{NO}+\mathrm{NO}_{2}\right)$ is decisive for ozone generation from shipping (Endresen et al., 2003). For the MFR in the ASO season the effect of diversion traffic on ozone is limited since it occurs (August-October) outside the months with maximum insolation. In September-October the sunlight in the Arctic is rapidly diminishing and ozone formation is getting less ef- ficient. In general substantial increases of 2 to above $5 \mathrm{ppv}$ (4 to above 10\%) are found in the Northern Hemisphere coastal and oceanic regions for the HIGH scenario. Many of the countries in western Europe see ozone increases on the order 3-6\%. In pristine regions of the tropical and Arctic Oceans the increases are above $10 \%$. In MJJ (not shown) the magnitude and spatial patterns of changes has many similarities to ASO. However, the changes in the Arctic are smaller since diversion traffic is absent, and larger over oceanic areas $30-60^{\circ} \mathrm{N}$ due to the maximum in photochemical activity.

The highest sulfate levels are found close to land-based sources such as industry and power plants in regions with high coal consumption (Fig. 3). The maximum concentrations are found in Asia. High sulfate levels are also found in regions with volcanic activity. Figure 3 shows that if the IMO regulations are applied successfully, future reductions are expected at mid-latitudes. The reductions are however smaller 

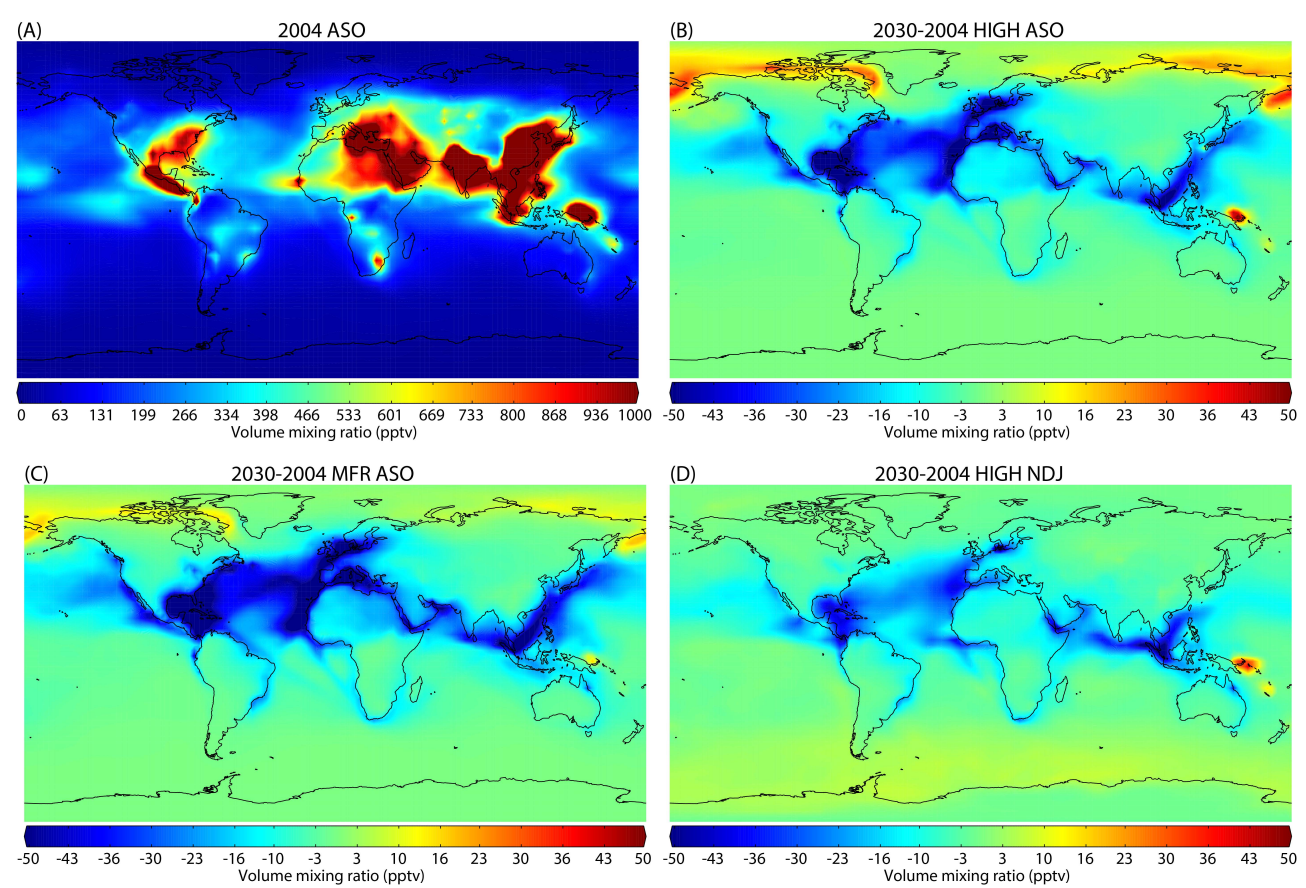

Fig. 3. Sulfate in the lowest model layer close to the surface (pptv). (A) Average 2004 for the months August-September-October (ASO). (B) Average change 2004-2030 HIGH scenario for the months ASO. (C) Same as (B), MFR scenario (D) Same as (B), HIGH scenario, months November-December-January (NDJ).

than the decrease of sulfur emissions. This is because most sulfur is emitted as $\mathrm{SO}_{2}$, and increases in oxidants $\left(\mathrm{OH}, \mathrm{O}_{3}\right.$ and $\mathrm{H}_{2} \mathrm{O}_{2}$ ) lead to more efficient sulfate formation. On the west coast of the continents with prevailing westerly winds, a reduction of around 50 pptv or $10-15 \%$ is clearly of significance, both with regard to health impact from particle pollution and acid precipitation. Effects of future sulfur regulations on particulate matter concentrations and mortality is discussed in detail in Lauer et al. (2009) and Winebrake et al. (2009). An increase of up to $50 \%$ is found for the ASO season for the HIGH scenario in proximity to the new diversion routes. This is expected as there are few other large sources of sulfur emissions close to these routes.

The highest surface concentrations of black carbon (BC) are found in China and India where biofuel use in households is common (Fig. 4). High levels are also found in other densely populated regions, megacities and areas with vegetation burning. Outside the Arctic future shipping leads to increased $\mathrm{BC}$ in the vicinity of major shipping routes. Typical increases are 3-20 $\mathrm{ng} \mathrm{m}^{-3}(10-20 \%)$ for the HIGH case, and somewhat lower for the MFR scenario. The largest absolute perturbations are found in the North Sea and other regions with much traffic. However, the largest relative increases are found in the less trafficked area near Antarctica due to the very low background values there. For the MFR scenario in the ASO season the Arctic has a decrease of about $10 \%$ in regions with internal traffic, and a similar or larger increase in the regions with diversion traffic. For the HIGH scenario, which has no measures on $\mathrm{BC}$ emissions, the situation is different. There is an increase in the whole of Arctic (Fig. 4), and the signals along the diversion routes are very evident. The BC levels increase more than $50 \%$ in much of the Arctic. Arctic changes are smallest in NDJ in both scenarios, mainly due to less traffic and emissions in winter.

The surface distribution of OC (Fig. 5) for 2004 shows many of the same source signatures as BC, but with a stronger signal around regions with vegetation fires. From 2004-2030 OC concentrations due to shipping decline in most regions, since $\mathrm{OC}$ emissions are correlated with $\mathrm{SO}_{\mathrm{x}}$ emissions and sulfur content is reduced following IMO regulations. Reductions are typically $4-20 \mathrm{ng} \mathrm{m}^{-3}$ near shipping lanes in the MFR case. This corresponds to a relative reduction of about $5 \%$ both at mid- and polar latitudes. The diversion routes in the ASO season are again an exception, with increases of $10-30 \%$ in the HIGH scenario.

\subsection{Global Radiative Forcing (RF)}

In Fig. 6 the RF from 2004 to 2030 due to the changed ship emissions is averaged globally over the whole year. Sulfate mainly influences (directly or indirectly) the radiation budget through reflection of sunlight. Except for the diversion season, regulations result in decreased sulfate concentrations both globally and in the Arctic (see Sect. 4.1). Therefore, the annual mean global forcings are positive. Sulfate has the largest contribution to the yearly mean total forcing, and is 

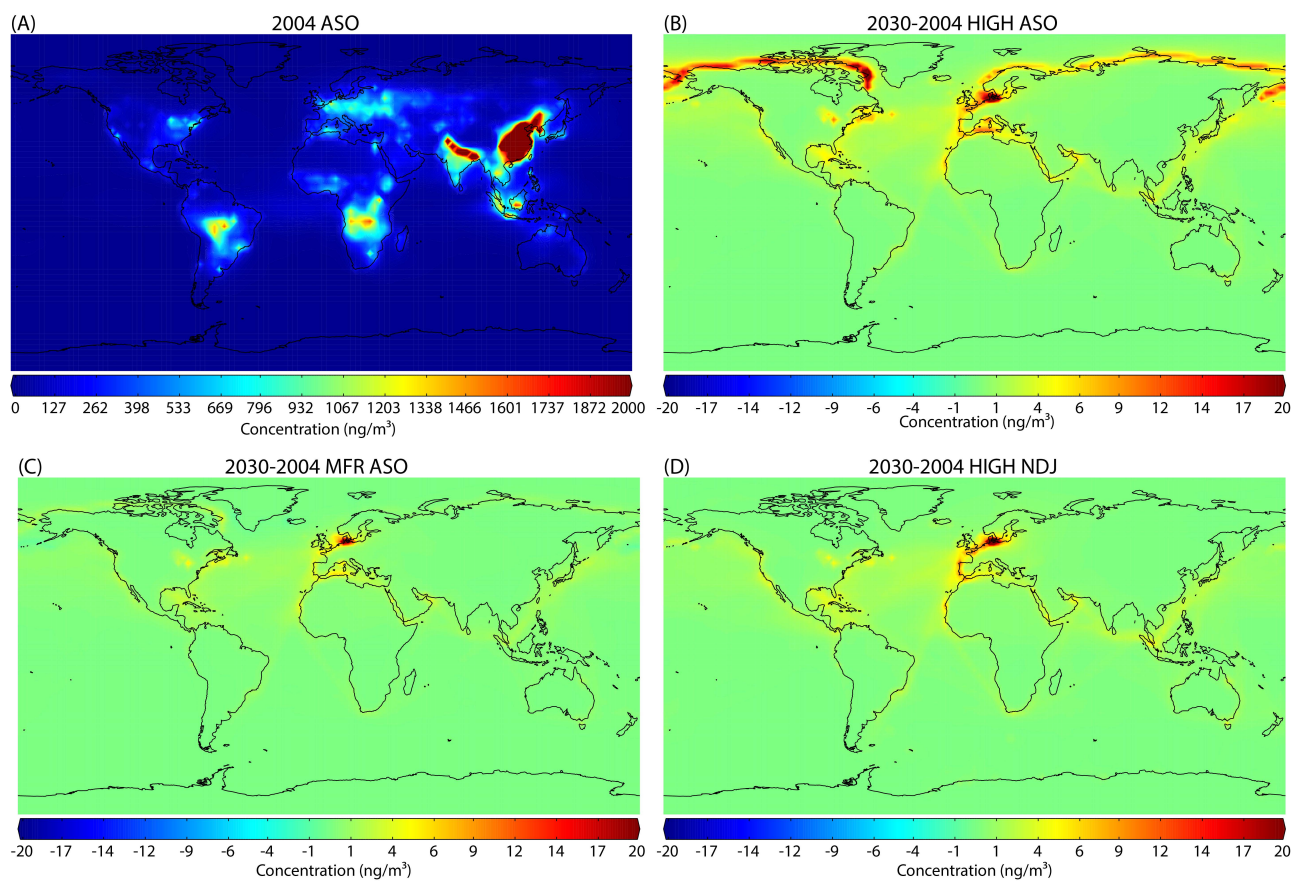

Fig. 4. Same as Fig. 3 for $\mathrm{BC}\left(\mathrm{ng} \mathrm{m}^{-3}\right)$.
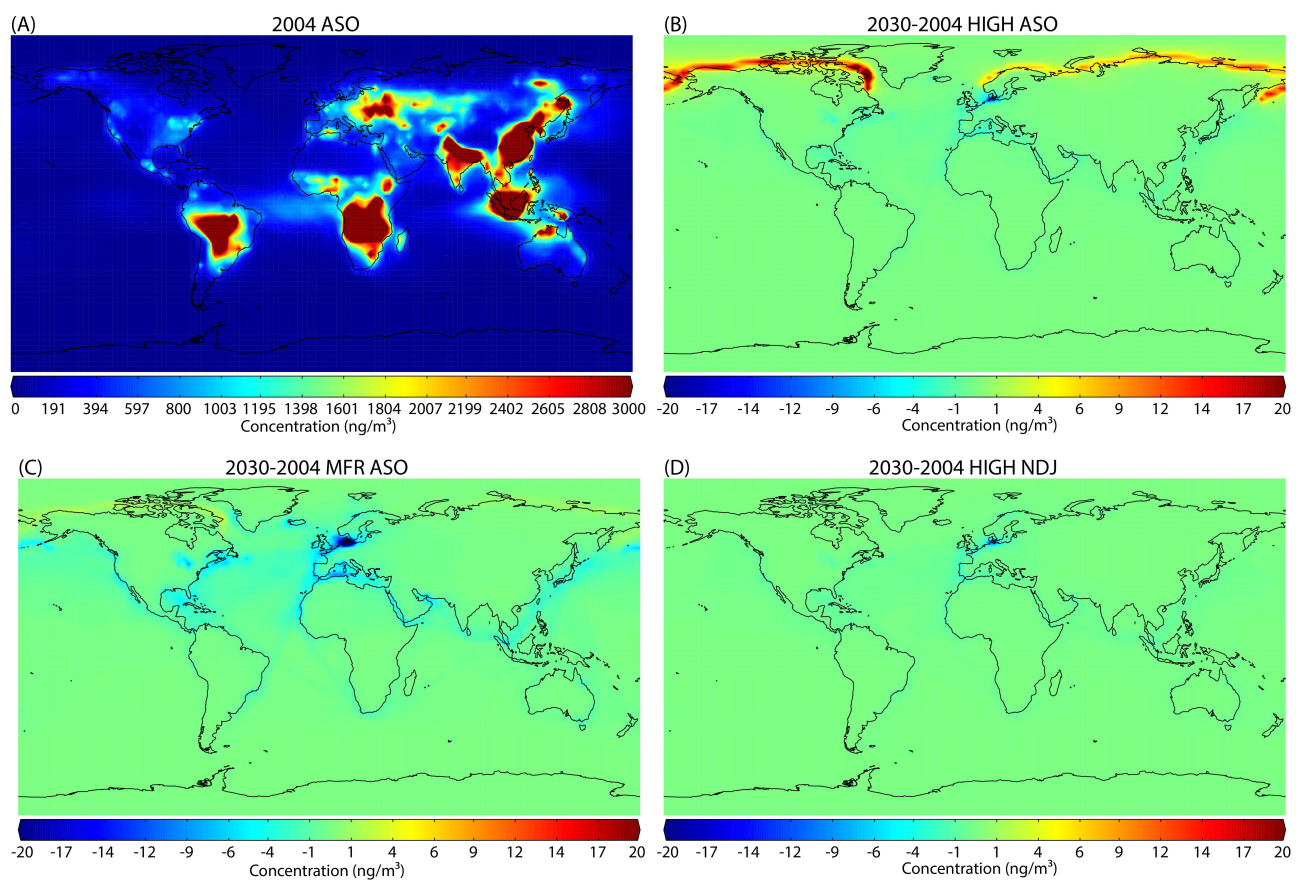

Fig. 5. Same as Fig. 3 for OC $\left(\mathrm{ng} \mathrm{m}^{-3}\right)$. 


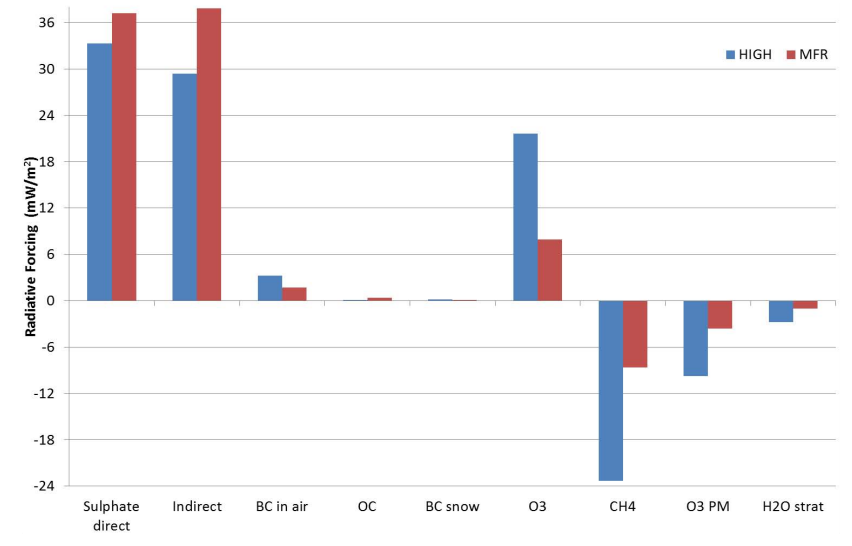

Fig. 6. Global RF (mW m ${ }^{-2}$ ) from 2004-2030 per component for the scenarios HIGH and MFR.

also the dominant cause of the indirect aerosol effect. The magnitudes of the direct sulfate and indirect aerosol effects are quite similar. Due to the strong reductions of sulfur emissions there are small differences in RF between the two scenarios. Interestingly, the difference is larger for the indirect effect than for the direct. We found that the normalized RFs with respect to burden are quite similar for the direct effects, and that there are nonlinearities from concentration changes to RF for the indirect effect. Sensitivity studies also suggest a logarithmic relation between emissions and the indirect effect (Lund et al., 2012). Ozone chemistry can also be nonlinear in regions with high background $\mathrm{NO}_{\mathrm{x}}$ levels. However, most shipping regions are relatively remote or moderately polluted and have shown quite linear responses in earlier studies (Eyring et al., 2007). The main cause of the difference of almost factor three in ozone RF between the two scenarios is therefore the span in $\mathrm{NO}_{\mathrm{x}}$ emissions (Table $1 b)$ rather than non-linearity. The RF signal from ozone in the HIGH scenario is almost as large as those from the indirect aerosol and direct sulfur effects. Ship emissions of methane are small and the direct radiative effects from these are negligible. Due to the relatively high $\mathrm{NO}_{\mathrm{x}}$ and low $\mathrm{CO}$ and NMVOCs emissions, shipping efficiently increases $\mathrm{OH}$ and thereby decreases methane lifetime by increasing the chemical loss. Methane changes in turn leads to changes in ozone, called Primary Mode (PM) ozone, and stratospheric water vapour. We therefore included simplified calculations of methane RF, even if methane is seldom defined as a short-lived climate forcer. We used the approach described in Berntsen et al. (2005) and Myhre et al. (2011) to calculate the global radiative forcings from methane and associated ozone and stratospheric water vapor changes. The RF values from this method apply for the time when the perturbations have reached equilibrium conditions. As in other shipping studies (Eyring et al., 2010) we find that the associated methane RF more than outweighs the positive RF from ozone changes

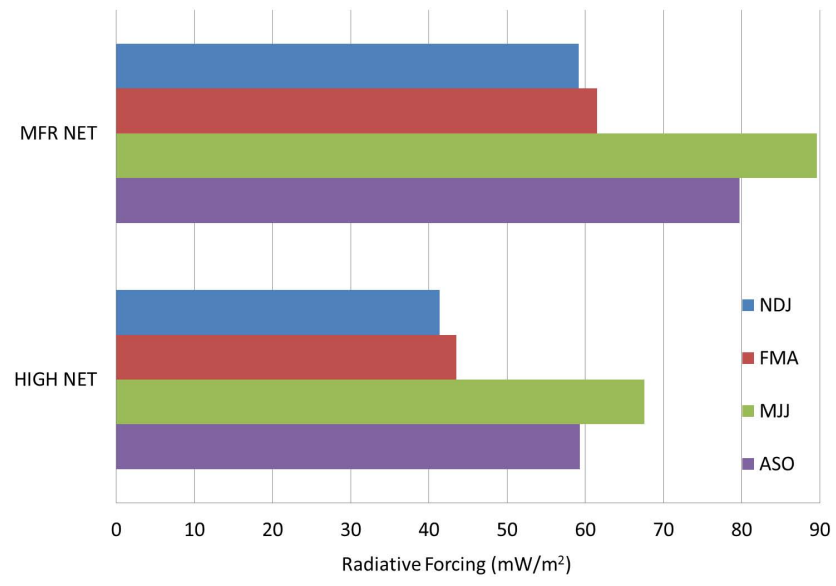

Fig. 7. Net global RF $\left(\mathrm{mW} \mathrm{m}^{-2}\right)$ from 2004-2030 for different seasons for the scenarios HIGH and MFR.

(Fig. 6). The contribution from $\mathrm{BC}$ and $\mathrm{OC}$ to global total RF is small, and nitrate RF is negligible.

The seasonality in global net 2004-2030 RF from ships is shown in Fig. 7. Seasonal differences are up to a factor 1.5. For the strongly scattering components (sulfate and OC) the magnitude of the RF is largest in the MJJ season, the season with largest insolation, in the regions of Northern Hemisphere where most ship emissions occur. Interestingly, the global RF for ozone is larger for the ASO season (Fig. 8) than the MJJ (not shown) even if one would expect photochemical activity in the Northern Hemisphere to be stronger in MJJ. BC RF is also higher for ASO. Global total ship emissions are slightly higher in ASO than MJJ, but this is likely not the main cause. As shown in Figs. 8 and 9 the strongest ozone and BC in air forcing is found over the region 20$30^{\circ} \mathrm{N}$ over Sahara and areas with low frequency of clouds (ozone) or high albedo (BC). The increase in column loading (not shown) in this area is larger for ASO. The difference is probably caused by the position and movement of the Inter Tropical Convergence Zone (ITCZ) resulting in less wet removal and stronger vertical transport of ozone precursors and $\mathrm{BC}$ in ASO. The RF for ozone is largest in the vicinity of the subtropical jets where ozone lifetime is long and ozone formation from precursors efficient. Even if the seasons of NDJ and ASO show quite different geographical signal for surface ozone changes (Fig. 2) the RF maps for these seasons (Fig. 8) are quite similar.

Figure 10 maps the direct sulfate RF and the indirect aerosol RF. The largest increases are found at low and midlatitudes. There are some signs of reductions in parts of the Arctic for the indirect effect due to increased sulfate concentrations near the diversion routes. However, the RF in the Arctic is in general small. Maximums in RF are mainly found over the mid latitude oceans. For the direct effect this is caused by the low albedo over oceans. For the indirect effect 

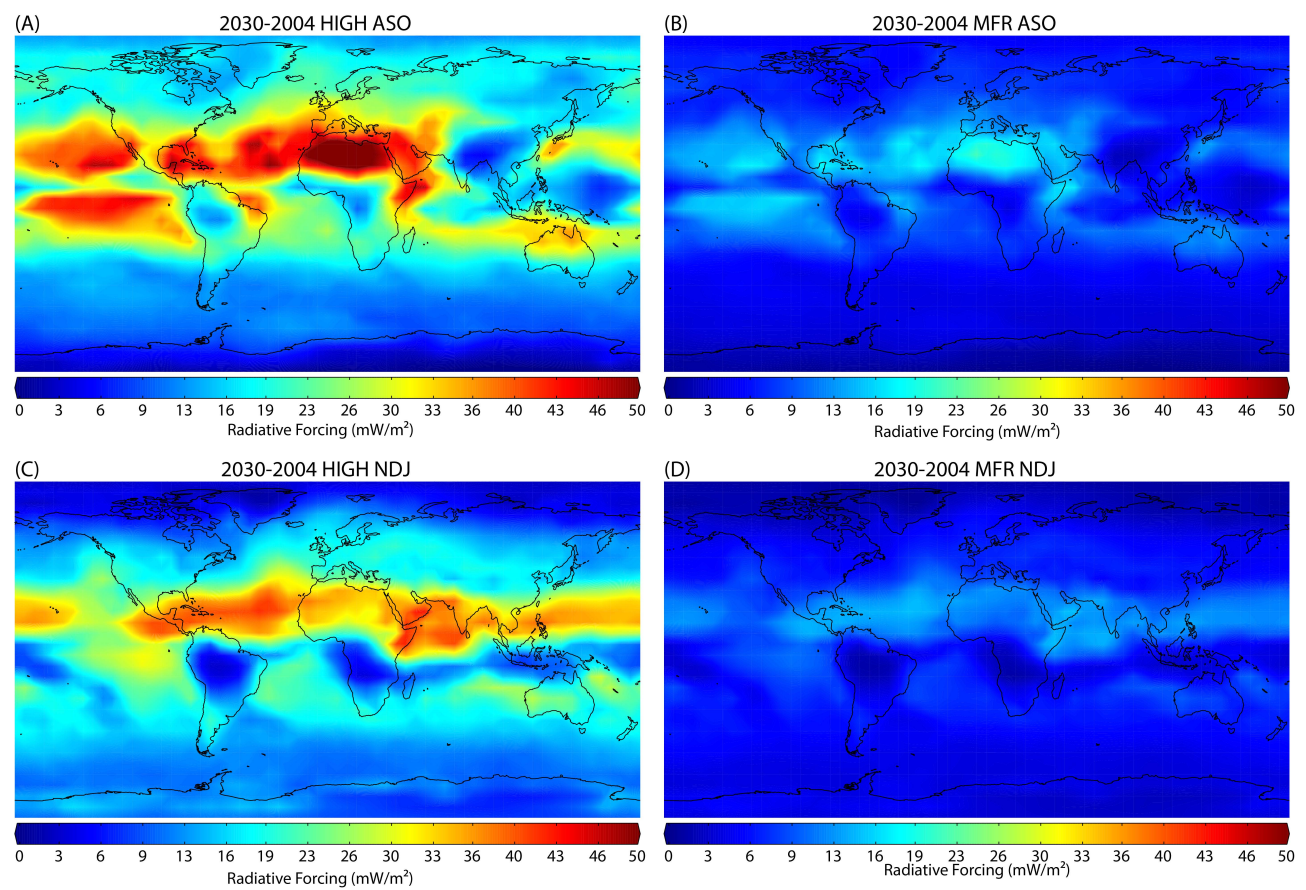

Fig. 8. Ozone RF 2004-2030 (mW m ${ }^{-2}$ ). (A) HIGH scenario, ASO season. (B) MFR scenario, ASO season. (C) HIGH scenario, NDJ season. (D) MFR scenario, NDJ season.
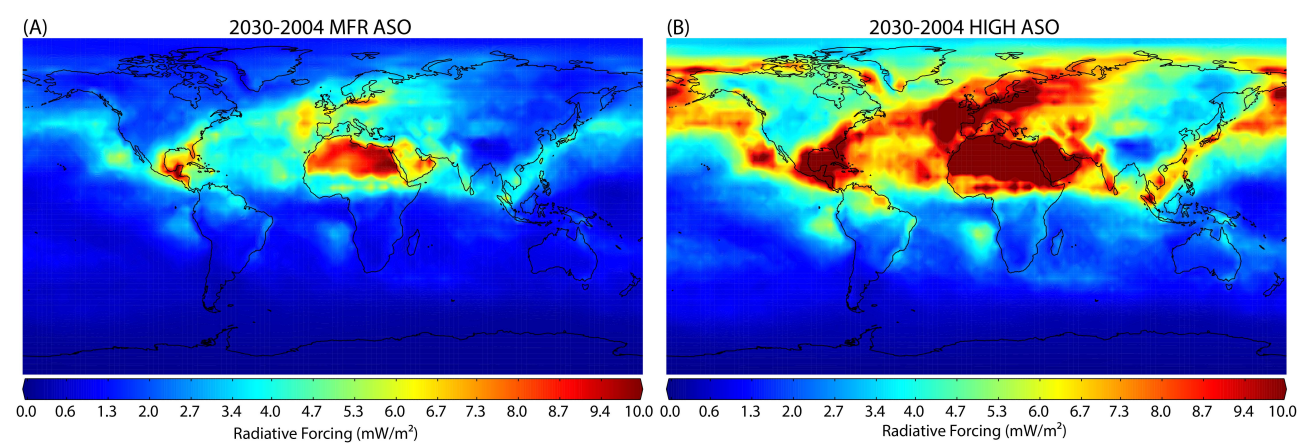

Fig. 9. BC in air RF 2004-2030 $\left(\mathrm{mW} \mathrm{m}^{-2}\right)$ for the ASO season. (A) MFR scenario. (B) HIGH scenario.

coincidence between high emissions and low level marine clouds is a decisive prerequisite.

For all species the RF is largest for the ship scenario with largest changes in emissions. With most components having a positive RF the overall result from 2004 to 2030 is a warming. Due to the important role of sulfur, the MFR scenario gives larger global mean total forcing than HIGH since it has the largest reduction in emissions. The global RFs for ozone and methane for the HIGH scenario are of comparable magnitude to RF from international shipping from pre-industrial to 2000 in studies with this model (Myhre et al., 2011; Endresen et al., 2003) as well as other models (Myhre et al., 2011; Eyring et al., 2010). Comparing with historical aerosol climate impacts (Eyring et al., 2010; Balkanski et al., 2010) the RFs from 2004-2030 (MFR and HIGH) are of similar magnitude for BC, and similar magnitude but of opposite sign for the direct sulfate RF. For the indirect effect and OC the values are also of opposite sign, but the absolute magnitude is smaller. The opposite signs are due to regulations of sulfur content in the fuel resulting in reduced sulfur and $O C$ emissions. This results in a net positive RF from 2004-2030 in contrast to the historical net RF from shipping that is negative. Since the individual RFs are of similar absolute magnitude over the short time frame 2004-2030 to those from 1850-2000, the numbers are clearly of significance. Furthermore the RF is positive (Fig. 6) for most components in the 2004-2030 period and it is therefore interesting to set it into perspective. The yearly average global net RFs for the shortlived climate forcers are $73 \mathrm{~mW} \mathrm{~m}^{-2}$ for the MFR scenario and $53 \mathrm{~mW} \mathrm{~m}^{-2}$ for the HIGH scenario. RF from $\mathrm{CO}_{2}$ and 

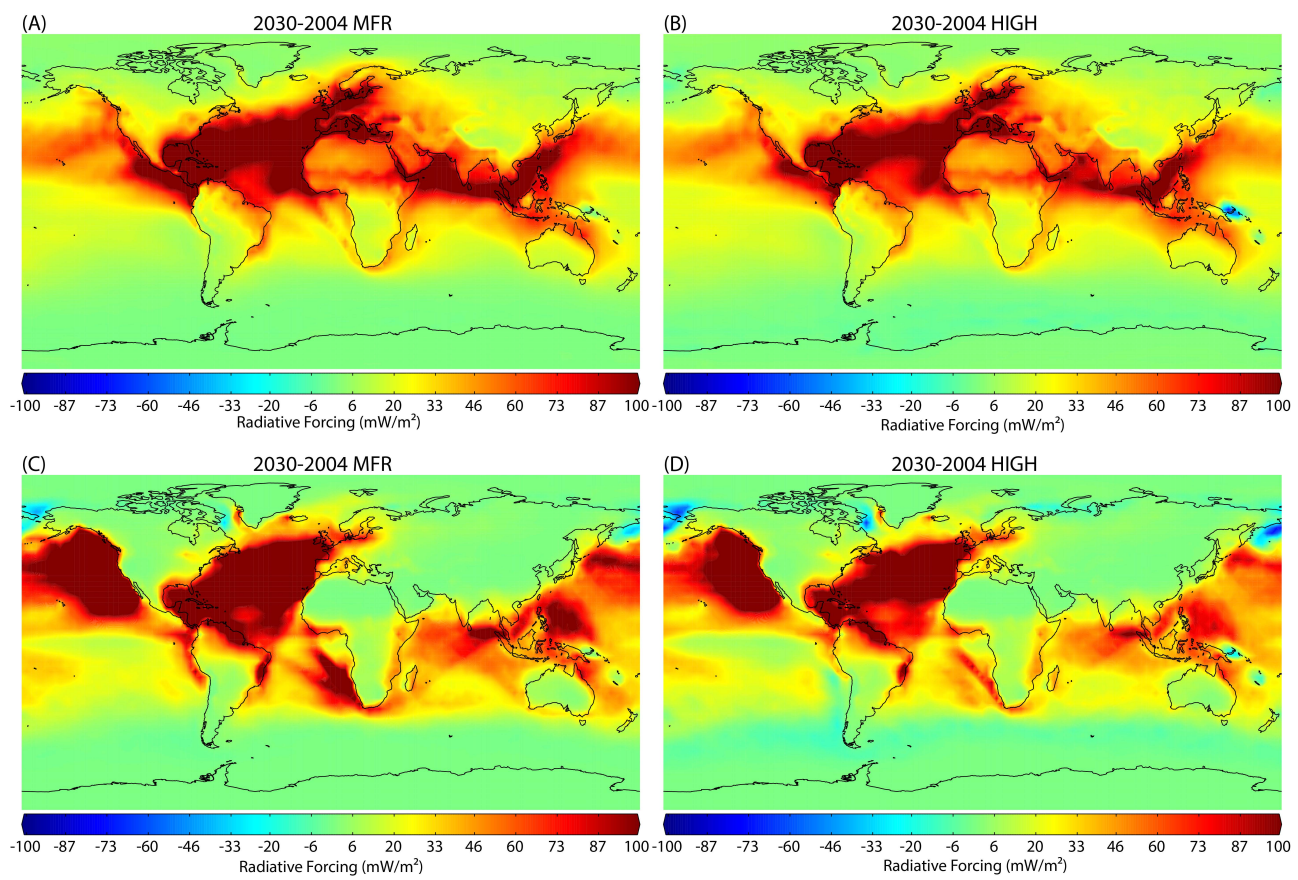

Fig. 10. Yearly mean sulfate direct RF 2004-2030 $\left(\mathrm{mW} \mathrm{m}^{-2}\right)$ for the MFR scenario (A) and HIGH scenario (B). Yearly mean first indirect aerosol RF 2004-2030 (mW m ${ }^{-2}$ ) for the MFR scenario (C) and HIGH scenario (D).

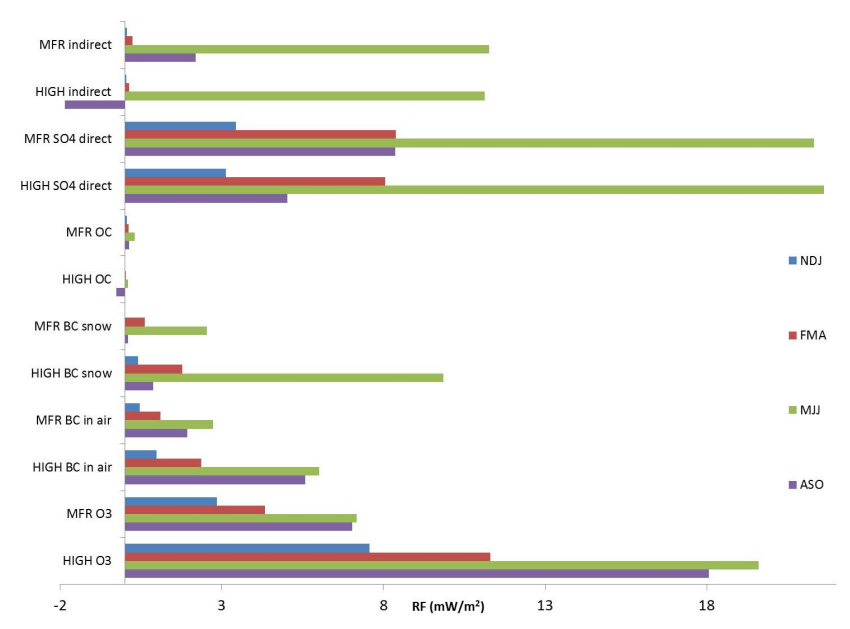

Fig. 11. RF 2004-2030 $\left(\mathrm{mW} \mathrm{m}^{-2}\right)$ in the Arctic $\left(60-90^{\circ} \mathrm{N}\right)$ for different seasons and components for the scenarios HIGH and MFR.

$\mathrm{N}_{2} \mathrm{O}$ is not accounted for in these numbers. These values are very similar to the numbers reported for historic aircraft $\mathrm{RF}$ in $2005,55 \mathrm{~mW} \mathrm{~m}^{-2}$ or $78 \mathrm{~mW} \mathrm{~m}^{-2}$ including cirrus cloud enhancement (Lee et al., 2010).

\subsection{Arctic Radiative Forcing (RF)}

Figure 11 shows the RF per component, seasonally averaged over $60-90^{\circ} \mathrm{N}$. In the Arctic the indirect aerosol effect is weaker than the direct sulfate RF due to less efficient cloud formation. The indirect effect is weak except for the MJJ season. It turns negative in the ASO HIGH case due to extensive sulfate increase in the Arctic connected with diversion traffic (also the case for OC RF). For MFR the direct sulfate effect is strongest with the indirect aerosol effect and ozone RF about equal as second most important. For the HIGH case ozone RF is strongest, and stronger than the direct sulfate RF except for the MJJ season. During the period with transit traffic (ASO) the ozone RF is more than double that of forcing from any other component in the HIGH case. BC forcing is of more significance in the Arctic than for the global mean. In the HIGH scenario the RF for $\mathrm{BC}$ on snow/ice in $\mathrm{MJJ}$ is large since this is the season with onset of snowmelt and $\mathrm{BC}$ has accumulated in snow throughout the winter. Averaged over the seasons the RF from $\mathrm{BC}$ in air and $\mathrm{BC}$ on snow/ice is approximately $60 \%$ lower for the Maximum Feasible Reduction (MFR) scenario. The RF from OC is almost negligible for both scenarios. Similar to Ødemark et al. (2012) we find the RF from nitrate to be negligible. There are large seasonal differences also when the Arctic RF is summed up for all components. The total RF is more than a factor 5 larger in the MJJ season than in the NDJ season. The factor is around 3 comparing MJJ and FMA.

Averaged over the year the overall RF for the HIGH scenario is a factor 1.5 larger than for the MFR scenario. This is opposite to the global picture (Sect. 4.2). The reason is the relatively stronger RF from ozone, $\mathrm{BC}$ in air and $\mathrm{BC}$ on snow/ice, and smaller indirect effect in the Arctic. 


\section{Discussion}

The ship emission scenarios used in this study are based on the state of understanding at the time the emission studies (Corbett et al., 2010a; Dalsøren et al., 2009) were performed. The development of $\mathrm{NO}_{\mathrm{x}}$ therefore follows global IMO regulations to be implemented by 2020 but does not include recently adopted regional Emission Control Areas (ECAs) that have more stringent standards. Recent findings also suggest that emissions of BC, particularly in the Arctic, will be very dependent on fuel type, speed and vessel type (Lack and Corbett, 2012). The emission factors used in the Dalsøren et al. (2009) and Corbett et al. (2010a) datasets forming the basis for the scenarios are similar, except for higher values for $\mathrm{BC}$ and $\mathrm{OC}$ in the Arctic inventory (Corbett et al., 2010a) taking into account recent findings by Lack et al. (2009). We might therefore underestimate the impact of $\mathrm{BC}$ and OC shipping emissions outside Arctic waters. However, this should not impact our conclusions since their impact is rather small compared to the signal from other components (e.g. Fig. 6). The organic matter (OM) emission factor used is an average from about 100 ship plume measurements and reports the OM after the semi-volatiles have either evaporated or condensed. Any formation of secondary species, and associated uncertainty is therefore linked to the VOC inventory and secondary organic aerosol (SOA) formation processes. The SOA scheme implemented in OsloCTM2 also shows small SOA values over the Arctic region (Hoyle et al., 2007). For these reasons only primary OC was included in the simulations.

Another uncertainty is the discontinuity at the overlap between the grid used for Arctic ship emissions (Corbett et al., 2010a) and the global traffic grid (Dalsøren et al., 2009) representing ship emissions for the rest of the globe. The inconsistency is unavoidable as the dataset from Corbett et al. (2010a) lacks global coverage. The result is too sharp or unrealistic concentrations gradients between the Arctic and mid latitudes close to shipping lanes for some primary pollutants. However, the effects are small on larger scales and therefore have little influence on our main findings. We assumed uniform changes in ship emissions 2004-2030 outside the Arctic region. Though international shipping is a global market with intercontinental transport, differences in regional development and new trade routes are likely. However, no studies currently address these aspects outside the Arctic.

In this study there were no changes from 2004 to 2030 in non-shipping emissions. This was done to be able to easily discern the impacts from changes in ship emissions. Dalsøren et al. (2007) found that the impact of shipping on ozone was quite independent of changes in emissions from other sectors in the period 2000-2015.

Eyring et al. (2007) performed multi-model calculations for ship emissions in 2030. One of the scenarios assumed a $2.2 \%$ annual growth from 2000 which is quite similar to the
MFR scenario. However, the results for MFR found here are not very well suited for comparison, as the assumed emission distributions are very different. The Eyring et al. (2007) study used a dataset only accounting for a few of the major trade routes. Granier et al. (2006) finds much larger increases in ozone and $\mathrm{NO}_{\mathrm{x}}$ along diversion routes than this study. The reasons for the differences are probably related to higher emissions in 2050, 0.65 and $1.3 \mathrm{Tg}(\mathrm{N})$ respectively, compared to $0.12 \mathrm{Tg}(\mathrm{N})$ in the HIGH case in 2030 in this study. Granier et al. (2006) also introduces the traffic one month earlier (July) and Arctic ship emissions are absent in their basis simulation whereas this study uses year 2004 emissions as basis. These factors would make ozone production more efficient in the Granier et al. (2006) study.

Changes in sea ice were not accounted for in the calculations. This might influence dry deposition and surface albedo and thereby the chemical composition and RF calculations. However, the new Arctic routes operate close to the coast and it is likely that ice-breakers will still be needed in 2030 (Peters et al., 2011). Scenarios for 2030 do not necessarily imply large changes in ice-extent. Taking into account changes in ice conditions on RF calculations are studied in Dalsøren et al. (2013) and found to have minor effects on RF from Arctic shipping. Identical atmospheric meteorology was used in the 2004 and 2030 simulations. Climate change towards 2030 makes changes in meteorological factors likely. Such changes were unaccounted for in this study.

The main reason that the Arctic temperatures currently rise twice as much as in the rest of the world is an amplification process involving snow, ice and albedo changes of the surface (Serreze and Barry, 2011). Increases in RF result in enhanced melting, and land or open water replace snow and ice. Both land and open water are, on average, less reflective than ice or snow, and thus absorb more solar radiation. This causes more warming which in turn may cause more melting. The pronounced seasonality of the RF signal is therefore interesting. We find a clear maximum of Arctic RF in MJJ which coincides with the melting season many places in the Arctic. The RFs for this season are $68 \mathrm{~mW} \mathrm{~m}^{-2}$ for the HIGH scenario and $45 \mathrm{~mW} \mathrm{~m}^{-2}$ for the MFR scenario. This is quite similar to the values reported in Sect. 4.2 for the global yearly mean RF. Through a comparison with global historical RF it was noted in Sect. 4.2 that these magnitudes are of significance.

Amendments to MARPOL Annex VI adopted by the International Maritime Organization in 2007 set limits on the sulfur content of fuel. This policy is intended to reduce surface level concentrations of secondary particulates and consequently, the health impacts associated with chronic exposures. An unintended consequence of this policy will be a short-lived warming effect at the global scale. An integrated view on climate and health impacts suggests alternative approaches to marine emissions control that may reduce these tradeoffs, particularly in the Arctic. For example, simultaneous $\mathrm{NO}_{\mathrm{x}}$ and black carbon emissions control in the Arctic, timed in parallel with sulfur emission reductions, could 
offset a significant share of $\mathrm{SO}_{\mathrm{x}}$-induced warming without compromising expected health benefits. Future studies of the spatial and temporal variation in climate and health impacts of marine emissions may reveal additional strategies to minimize near-term warming. The purpose of the MFR scenario is to reduce $\mathrm{BC}$ in the Arctic region. The calculations shows that this is successful as the RF from $\mathrm{BC}$ in air and $\mathrm{BC}$ on snow/ice is approximately $60 \%$ lower for MFR compared to the HIGH scenario. However, we find an ozone RF in the Arctic that is larger than the BC RF. This suggests that it could also be efficient to reduce $\mathrm{NO}_{\mathrm{x}}$ emissions. Though the positive ozone RF may be compensated by negative methane RF, the methane RF from shipping is small in the Arctic (Ødemark et al., 2012) due to inefficient formation of $\mathrm{OH}$ and low temperatures. Several oceanic regions are decided or considered as ECA (Emission Control Areas) for $\mathrm{NO}_{\mathrm{x}}$. Though the ECAs are mainly set to limit air pollution, the Arctic could be a candidate as an ECA from a climate perspective. A sensitivity study revealed that $2 / 3$ of the calculated ozone increase in the HIGH scenario was due to emission within the region $\left(60-90^{\circ} \mathrm{N}\right)$, the rest was due to transport from lower latitudes. It should however be noted that this study might overestimate the concentration change and RF of ozone due to the coarse resolution in the simulations with the OsloCTM2 model. Not resolving the scales of the chemical and physical processes in the exhaust plumes might lead to prediction of too high ozone production per emitted $\mathrm{NO}_{\mathrm{x}}$ molecule (Paoli et al., 2011). The effect of an Arctic ECA would be less if plume chemistry reduces ozone production efficiency in the Arctic similar to what studies indicate for low latitudes.

The interpretation of how the Arctic RF from a particular component affects Arctic and global temperatures is subject to some uncertainty. It is not necessarily the case that a positive RF implies a regional temperature increase. Shindell and Faluvegi (2009), Sand et al. (2013) and Flanner (2013) found that positive RF for some atmospheric species in the Arctic could result in cooling in the region due to complex atmospheric circulation changes. More studies on these issues are needed, involving separate emission sectors and the whole cause effect chain from emissions to temperature change.

\section{Conclusions}

In this study we compare environmental and climate impacts, in terms of surface concentrations and RF, of high and low estimates for ship emissions in 2030. Impacts in the Arctic are the main focus. In the high growth scenario (HIGH) there is a large increase in ship traffic within the Arctic. In addition $2 \%$ of the yearly global traffic diverts to Arctic throughroutes during late summer. Global shipping growth outside the Arctic is $+3.3 \%$ per year. In the Maximum Feasible Reduction (MFR) scenario a business as usual scenario is followed but maximum feasible reduction is applied on Arctic
$\mathrm{BC}$ emissions (also affecting OC). In this scenario, $1 \%$ of the global traffic (the business as usual scenario from Corbett et al., 2010a) diverts to Arctic through-routes. Global shipping growth outside the Arctic is $+2.1 \%$ per year. Counteracting the traffic growth in both scenarios is a phase in of existing regulations, resulting in reduced emission factors for some components. The emission scenarios are described in detail in Corbett et al. (2010a).

For all species tropospheric concentration changes vary strongly in magnitude and distribution with season, in particular in the Arctic where photochemistry is most active during a few summer months. In both future scenarios the surface $\mathrm{NO}_{2}$ changes are found close to or within the shipping lanes. Increases from 2004 to 2030 are typically in the range $10 \%$ to above $60 \%$ in coastal regions of the Northern Hemisphere, Arctic shipping regions, and main oceans shipping lanes in both hemispheres. In late summer, when operation takes place along the diversion routes, increases are above $200 \%$ in pristine regions of the Arctic. The largest $\mathrm{NO}_{2}$ changes are found for the HIGH scenario. For surface ozone the HIGH scenario shows substantial increases of 2 to above $5 \mathrm{ppv}$ (4 to above $10 \%$ ) in coastal and oceanic regions of the Northern Hemisphere. In pristine regions of the tropical and Arctic Oceans the increases are above $10 \%$. The changes in the MFR scenario are moderate and a few ppbv/percent over the oceans and coastal areas. The ozone RF has a quite different geographical distribution than surface ozone. Largest 2004-2030 ozone RF is found near the subtropical jets and results from a combination of more efficient vertical transport and ozone formation, and low cloud cover. The largest absolute surface BC increases are found in the North Sea and other regions with much traffic. In late summer the MFR scenario has a decrease of about $10 \%$ in Arctic regions with internal traffic, and a similar or larger increase in the regions with diversion traffic. For the HIGH scenario the BC levels increase more than $50 \%$ in much of the Arctic in late summer. Like ozone, maximum RF from BC in air occurs at low latitudes. The strongest RF is found over Sahara due to high surface albedo and strong solar radiation.

Due to regulations, reductions in future sulfate levels are found at mid-latitudes. On the west coast of the continents reduction around $50 \mathrm{pptv}$ or $10-15 \%$ is important and could reduce health impact from particle pollution and acid precipitation. Increases (up to $50 \%$ ) are only found in regions near the diversion routes in the Arctic in the months of operation. Due to sulfate reductions the 2004-2030 direct sulfate $\mathrm{RF}$ as well as the indirect RF is positive. Maximums in RF are mainly found over the mid latitude oceans. OC emissions correlate with sulfur emissions and surface OC shows relative reductions of about $5 \%$ both at mid and polar latitudes. The diversion routes in the late summer season are an exception to this, with increases of $10-30 \%$ in the HIGH scenario. The RFs from the OC changes are small compared to the other components. 
Sulfate has the largest contribution to the global yearly mean forcing. Though, in the HIGH scenario the ozone RF is almost as large as those from the indirect aerosol and direct sulfur effects. Simplified calculations show that methane and associated RF are of about similar magnitude but opposite sign to the ozone RF for both scenarios. The contribution from $\mathrm{BC}, \mathrm{OC}$ and nitrate to global RF is small. With sulfur reductions most components have a positive RF and the overall result from 2004 to 2030 is a warming, in contrast to the historical net RF from shipping which is negative. For several components the RFs from 2004-2030 in this study are of comparable absolute magnitude to the RF from international shipping from pre-industrial to 2000 , as found in studies with this or other models. The MFR scenario gives larger global mean net forcing since it has the largest reduction in sulfur emissions. The yearly average global net RFs for the shortlived climate forcers are $73 \mathrm{~mW} \mathrm{~m}^{-2}$ for the MFR scenario and $53 \mathrm{~mW} \mathrm{~m}^{-2}$ for the HIGH scenario. The positive RFs from $\mathrm{N}_{2} \mathrm{O}$ and $\mathrm{CO}_{2}$ are not included in these numbers. The shipping RF from 2004-2030 is about equal to the historic aircraft RF up to $2005\left(55 \mathrm{~mW} \mathrm{~m}^{-2}\right.$ or $78 \mathrm{~mW} \mathrm{~m}^{-2}$ including cirrus cloud enhancement, Lee et al., 2010).

Very large seasonal variations (up to a factor of 10) are found for Arctic RF. The indirect effect is small except for the spring season. It turns negative for a few months in the HIGH case due to extensive sulfate increase connected with diversion traffic (also the case for OC RF). In MFR the direct sulfate effect dominates yearly mean Arctic RF, with the indirect and ozone RF about equal as second most important. For the HIGH case ozone RF is largest except for the spring season. During the period with transit traffic the ozone RF is more than twice as large as forcing from any other component in the HIGH case. BC forcing is of more significance in the Arctic than for the global mean, especially BC on snow/ice during the snowmelt period in spring in the HIGH scenario. The RF from OC and nitrate is almost negligible for both scenarios. Averaged over the year the overall Arctic RF for the HIGH scenario is a factor of 1.5 larger than for the MFR scenario. This is opposite to the global picture. The reason is the relatively larger ozone and BC RFs and smaller indirect effect in the Arctic. Despite maximum in shipping emissions in summer and early autumn we find a clear maximum of RF in spring-early summer coinciding with the melting season. The total RF is more than a factor 2 larger from May to July compared to the yearly average.

We find that phasing in of existing IMO regulations on sulfate are efficient in reducing particle pollution both globally and in the Arctic. The tradeoff is that it leads to positive radiative forcing (Fuglestvedt et al., 2009). Though BC emissions from shipping are much smaller, measures are favored by both reductions in air pollution and radiative forcing. The $\mathrm{RF}$ from BC in the Arctic is approximately $60 \%$ lower in the Maximum Feasible Reduction scenario. In the Arctic, regulations of $\mathrm{NO}_{\mathrm{x}}$ could also be favorable both for air quality and climate. Ozone is reduced and the compensating $\mathrm{NO}_{\mathrm{x}}$ induced methane RF is small in the Arctic. We find an ozone RF in the Arctic that is larger than the BC RF. The Arctic could thereby be a candidate as an Emission Control Area (ECA) for $\mathrm{NO}_{\mathrm{x}}$.

Acknowledgements. This work was funded by EU project ACCESS (Arctic Climate Change Economy and Society) and the Norwegian Research Council project ArcAct (project number 184873/S30, "Unlocking the Arctic Ocean: The climate impact of increased shipping and petroleum activities (ArcAct)").

Edited by: K. Carslaw

\section{References}

Arctic Council: Arctic Marine Shipping Assessment 2009 Report, Arctic Council, 2009.

Balkanski, Y., Myhre, G., Gauss, M., Rädel, G., Highwood, E. J., and Shine, K. P.: Direct radiative effect of aerosols emitted by transport: from road, shipping and aviation, Atmos. Chem. Phys., 10, 4477-4489, doi:10.5194/acp-10-4477-2010, 2010.

Berglen, T., Berntsen, T., Isaksen, I., and Sundet, J.: A global model of the coupled sulfur/oxidant chemistry in the troposphere: The sulfur cycle, J. Geophys. Res.-Atmos., 109, D19310, doi:10.1029/2003JD003948, 2004.

Berntsen, T. K., Fuglestvedt, J. S., Joshi, M. M., Shine, K. P., Stuber, N., Ponater, M., Sausen, R., Hauglustaine, D. A., and Li, L.: Response of climate to regional emissions of ozone precursors: sensitivities and warming potentials, Tellus B, 57, 283-304, 2005.

Buhaug, Ø., Corbett, J. J., Endresen, Ø., Eyring, V., Faber, J., Hanayama, S., Lee, D. S., Lee, D., Lindstad, H., Markowska, A. Z., Mjelde, A., Nelissen, D., Nilsen, J., Pålsson, C., Winebrake, J. J., Wu, W., and Yoshida, K.: Second IMO GHG Study 2009, International Maritime Organization (IMO), London, UK, 2009.

Cofala, J., Klimont, Z., Amann, M., Bertok, I., Heyes, C., Rafaj, P., Schöpp, W., and Wagner, F.: Final Report: Analysis of Policy Measures to Reduce Ship Emissions in the Context of the Revision of the National Emissions Ceilings Directive, International Institute for Applied Systems Analysis, Laxenburg, Austria, 2007.

Corbett, J. J., Lack, D. A., Winebrake, J. J., Harder, S., Silberman, J. A., and Gold, M.: Arctic shipping emissions inventories and future scenarios, Atmos. Chem. Phys., 10, 9689-9704, doi:10.5194/acp-10-9689-2010, 2010a.

Corbett, J. J., Winebrake, J. J., and Green, E. H.: An assessment of technologies for reducing regional short-lived climate forcers emitted by ships with implications for Arctic shipping, Carbon Management, 1, 207-225, 2010b.

Dalsøren, S., Endresen, O., Isaksen, I., Gravir, G., and Sorgard, E.: Environmental impacts of the expected increase in sea transportation, with a particular focus on oil and gas scenarios for Norway and northwest Russia, J. Geophys. Res.-Atmos., 102, D02310, doi:10.1029/2005JD006927, 2007.

Dalsøren, S. B., Eide, M. S., Endresen, Ø., Mjelde, A., Gravir, G., and Isaksen, I. S. A.: Update on emissions and environmental impacts from the international fleet of ships: the contribution from 
major ship types and ports, Atmos. Chem. Phys., 9, 2171-2194, doi:10.5194/acp-9-2171-2009, 2009.

Dalsøren, S., Eide, M., Myhre, G., Endresen, O., Isaksen, I., and Fuglestvedt, J.: Impacts of the Large Increase in International Ship Traffic 2000-2007 on Tropospheric Ozone and Methane, Environ. Sci. Technol., 44, 2482-2489, doi:10.1021/es902628e, 2010.

Dalsøren, S. B., Samset, B. H., Myhre, G., Berntsen, T. K., Fuglestvedt, J. S., and Ødemark, K.: Short-lived climate forcers from future shipping and petroleum activities in the Arctic, in preparation, 2013.

Eide, M. S.: Ship Emissions of the Future. Technical Report No 2007-1325, Det Norske Veritas, Høvik, Norway, 2007.

Endresen, O., Sorgard, E., Sundet, J., Dalsøren, S., Isaksen, I., Berglen, T., and Gravir, G.: Emission from international sea transportation and environmental impact, J. Geophys. Res.Atmos., 108, 4560, doi:10.1029/2002JD002898, 2003.

Eyring, V., Kohler, H., Lauer, A., and Lemper, B.: Emissions from international shipping: 2. Impact of future technologies on scenarios until 2050, J. Geophys. Res.-Atmos., 110, D17306, doi:10.1029/2004JD005620, 2005.

Eyring, V., Stevenson, D. S., Lauer, A., Dentener, F. J., Butler, T., Collins, W. J., Ellingsen, K., Gauss, M., Hauglustaine, D. A., Isaksen, I. S. A., Lawrence, M. G., Richter, A., Rodriguez, J. M., Sanderson, M., Strahan, S. E., Sudo, K., Szopa, S., van Noije, T. P. C., and Wild, O.: Multi-model simulations of the impact of international shipping on Atmospheric Chemistry and Climate in 2000 and 2030, Atmos. Chem. Phys., 7, 757-780, doi:10.5194/acp-7-757-2007, 2007.

Eyring, V., Isaksen, I. S. A., Berntsen, T., Collins, W. J., Corbett, J. J., Endresen, O., Grainger, R. G., Moldanova, J., Schlager, H., and Stevenson, D. S.: Transport impacts on atmosphere and climate: Shipping, Atmospheric Environment, 44, 4735-4771, doi:10.1016/j.atmosenv.2009.04.059, 2010.

Flanner, M. G.:Arctic climate sensitivity to local black carbon, J. Geophys. Res., doi:10.1002/jgrd.50176, accepted, 2013.

Fuglestvedt, J., Berntsen, T., Eyring, V., Isaksen, I., Lee, D., and Sausen, R.: Shipping Emissions: From Cooling to Warming of Climate-and Reducing Impacts on Health, Environ. Sci. Technol., 43, 9057-9062, doi:10.1021/es901944r, 2009.

Granier, C., Niemeier, U., Jungclaus, J. H., Emmons, L., Hess, P., Lamarque, J. F., Walters, S., and Brasseur, G. P.: Ozone pollution from future ship traffic in the Arctic northern passages, Geophys. Res. Lett., 33, L13807, doi:10.1029/2006g1026180, 2006.

Hoor, P., Borken-Kleefeld, J., Caro, D., Dessens, O., Endresen, O., Gauss, M., Grewe, V., Hauglustaine, D., Isaksen, I. S. A., Jöckel, P., Lelieveld, J., Myhre, G., Meijer, E., Olivie, D., Prather, M., Schnadt Poberaj, C., Shine, K. P., Staehelin, J., Tang, Q., van Aardenne, J., van Velthoven, P., and Sausen, R.: The impact of traffic emissions on atmospheric ozone and $\mathrm{OH}$ : results from QUANTIFY, Atmos. Chem. Phys., 9, 3113-3136, doi:10.5194/acp-9-3113-2009, 2009.

Hoyle, C. R., Berntsen, T., Myhre, G., and Isaksen, I. S. A.: Secondary organic aerosol in the global aerosol - chemical transport model Oslo CTM2, Atmos. Chem. Phys., 7, 5675-5694, doi:10.5194/acp-7-5675-2007, 2007.

Lack, D. A. and Corbett, J. J.: Black carbon from ships: a review of the effects of ship speed, fuel quality and exhaust gas scrubbing, Atmos. Chem. Phys., 12, 3985-4000, doi:10.5194/acp-12-3985-
2012, 2012.

Lack, D., Corbett, J., Onasch, T., Lerner, B., Massoli, P., Quinn, P., Bates, T., Covert, D., Coffman, D., Sierau, B., Herndon, S., Allan, J., Baynard, T., Lovejoy, E., Ravishankara, A., and Williams, E.: Particulate emissions from commercial shipping: Chemical, physical, and optical properties, J. Geophys. Res.-Atmos., 114, 2156-2202, doi:10.1029/2008JD011300, 2009.

Lauer, A., Eyring, V., Corbett, J., Wang, C., and Winebrake, J.: Assessment of Near-Future Policy Instruments for Oceangoing Shipping: Impact on Atmospheric Aerosol Burdens and the Earth's Radiation Budget, Environ. Sci. Technol., 43, 55925598, doi:10.1021/es900922h, 2009.

Lee, D. S., Pitari, G., Grewe, V., Gierens, K., Penner, J. E., Petzold, A., Prather, M. J., Schumann, U., Bais, A., Berntsen, T., Iachetti, D., Lim, L. L., and Sausen, R.: Transport impacts on atmosphere and climate: Aviation, Atmos. Environ., 44, 46784734, doi:10.1016/j.atmosenv.2009.06.005, 2010.

Lemke, P., Ren, J., Alley, R., Allison, I., Carrasco, J., Flato, G., Fujii, Y., Kaser, G., Mote, P., Thomas, R., and Zhang, T.: Observations: change in snow, ice and frozen ground. Climate Change 2007:The Physical Science Basis. Contribution of Working Group I to the Fourth Assessment Report of the Intergovernmental Panel on Climate Change (Cambridge: Cambridge University Press), 2007.

Lund, M. T., Eyring, V., Fuglestvedt, J. S., Hendricks, J., Lauer, A., Lee, D., and Righi, M.: Global-Mean Temperature Change from Shipping toward 2050: Improved Representation of the Indirect Aerosol Effect in Simple Climate Models, Environ. Sci. Technol., 46, 8868-8877, doi:10.1021/es301166e, 2012.

Meehl, G. H., Stocker, T. F., Collins, W. D., Friedlingstein, P., Gaye, A. T., Gregory, J. M., Kito, A., Knutti, R., Murphy, J. M., Noda, A., Raper, S. C. B., Watterson, I. G., Weaver, A. J., and Zhao, Z.-C.: Global climate projections., Cambridge University Press, Cambridge, 747-846, 2007.

Molders, N., Porter, S., Cahill, C., and Grell, G.: Influence of ship emissions on air quality and input of contaminants in southern Alaska National Parks and Wilderness Areas during the 2006 tourist season, Atmos. Environ., 44, 1400-1413, doi:10.1016/j.atmosenv.2010.02.003, 2010.

Myhre, G., Bellouin, N., Berglen, T., Berntsen, T., Boucher, O., Grini, A., Isaksen, I., Johnsrud, M., Mishchenko, M., Stordal, F., and Tanre, D.: Comparison of the radiative properties and direct radiative effect of aerosols from a global aerosol model and remote sensing data over ocean, Tellus B, 59, 115-129, doi:10.1111/j.1600-0889.2006.00226.x, 2007.

Myhre, G., Berglen, T. F., Johnsrud, M., Hoyle, C. R., Berntsen, T. K., Christopher, S. A., Fahey, D. W., Isaksen, I. S. A., Jones, T. A., Kahn, R. A., Loeb, N., Quinn, P., Remer, L., Schwarz, J. P., and Yttri, K. E.: Modelled radiative forcing of the direct aerosol effect with multi-observation evaluation, Atmos. Chem. Phys., 9, 1365-1392, doi:10.5194/acp-9-1365-2009, 2009.

Myhre, G., Shine, K., Radel, G., Gauss, M., Isaksen, I., Tang, Q., Prather, M., Williams, J., van Velthoven, P., Dessens, O., Koffi, B., Szopa, S., Hoor, R., Grewe, V., Borken-Kleefeld, J., Berntsen, T., and Fuglestvedt, J.: Radiative forcing due to changes in ozone and methane caused by the transport sector, Atmos. Environ., 45, 387-394, doi:10.1016/j.atmosenv.2010.10.001, 2011.

Ødemark, K., Dalsøren, S. B., Samset, B. H., Berntsen, T. K., Fuglestvedt, J. S., and Myhre, G.: Short-lived climate forcers from 
current shipping and petroleum activities in the Arctic, Atmos. Chem. Phys., 12, 1979-1993, doi:10.5194/acp-12-1979-2012, 2012.

Olivier, J. G. J., Van Aardenne, J. A., Dentener, F., Ganzeveld, L., and Peters, J. A. H. W.: Recent trends in global greenhouse gas emissions: regional trends and spatial distribution of key sources, in: Non-CO2 Greenhouse Gases (NCGG-4), edited by: Van Amstaal, A., Millpress, Rotterdam, 325-330, 2005.

Paoli, R., Cariolle, D., and Sausen, R.: Review of effective emissions modeling and computation, Geosci. Model Dev., 4, 643667, doi:10.5194/gmd-4-643-2011, 2011.

Paxian, A., Eyring, V., Beer, W., Sausen, R., and Wright, C.: Present-Day and Future Global Bottom-Up Ship Emission Inventories Including Polar Routes, Environ. Sci. Technol., 44, 13331339, doi:10.1021/es9022859, 2010.

Peters, G. P., Nilssen, T. B., Lindholt, L., Eide, M. S., Glomsrød, S., Eide, L. I., and Fuglestvedt, J. S.: Future emissions from shipping and petroleum activities in the Arctic, Atmos. Chem. Phys., 11, 5305-5320, doi:10.5194/acp-11-5305-2011, 2011.

Quaas, J. and Boucher, O.: Constraining the first aerosol indirect radiative forcing in the LMDZ GCM using POLDER and MODIS satellite data, Geophys. Res. Lett., 32, L17814, doi:10.1029/2005g1023850, 2005.

Quaas, J., Boucher, O., and Lohmann, U.: Constraining the total aerosol indirect effect in the LMDZ and ECHAM4 GCMs using MODIS satellite data, Atmos. Chem. Phys., 6, 947-955, doi:10.5194/acp-6-947-2006, 2006.

Sand, M., Berntsen, T. K., Kay, J. E., Lamarque, J. F., Seland, $\varnothing$., and Kirkevåg, A.: The Arctic response to remote and local forcing of black carbon, Atmos. Chem. Phys., 13, 211-224, doi:10.5194/acp-13-211-2013, 2013.

Schultz, M., Bolscher, M. v. h., Pulles, T., Brand, R., Pereira, J., and Spessa, A.: A global data set of anthropogenic $\mathrm{CO}, \mathrm{NO}_{\mathrm{x}}$, and NMVOC emissions, Workpacage 1, Deliverable D1-6, EUContract No. EVK2-CT-2002-00170, available at: http://retro. enes.org/reports/D1-6_final.pdf, 2007.

Serreze, M. C. and Barry, R. G.: Processes and impacts of Arctic amplification: A research synthesis, Global Planet. Change, 77, 85-96, doi:10.1016/j.gloplacha.2011.03.004, 2011.
Serreze, M., Holland, M., and Stroeve, J.: Perspectives on the Arctic's shrinking sea-ice cover, Science, 315, 1533-1536, doi:10.1126/science.1139426, 2007.

Shindell, D. and Faluvegi, G.: Climate response to regional radiative forcing during the twentieth century, Nature Geosci., 2, 294-300, doi:10.1038/ngeo473, 2009.

Skeie, R. B., Fuglestvedt, J., Berntsen, T., Lund, M. T., Myhre, G., and Rypdal, K.: Global temperature change from the transport sectors: Historical development and future scenarios, Atmos. Environ., 43, 6260-6270, doi:10.1016/j.atmosenv.2009.05.025, 2009.

Skeie, R. B., Berntsen, T., Myhre, G., Pedersen, C. A., Ström, J., Gerland, S., and Ogren, J. A.: Black carbon in the atmosphere and snow, from pre-industrial times until present, Atmos. Chem. Phys., 11, 6809-6836, doi:10.5194/acp-11-6809-2011, 2011 a.

Skeie, R. B., Berntsen, T. K., Myhre, G., Tanaka, K., Kvalevåg, M. M., and Hoyle, C. R.: Anthropogenic radiative forcing time series from pre-industrial times until 2010, Atmos. Chem. Phys., 11, 11827-11857, doi:10.5194/acp-11-11827-2011, 2011 b.

Stamnes, K., Tsay, S., Wiscombe, W., and Jayaweera, K.: Numerically stable algorithm for discrete-ordinate-method radiative transfer in multiple scattering and emitting layered media, Appl. Optics, 27, 2502-2509, 1988.

Stephenson, S., Smith, L., and Agnew, J.: Divergent long-term trajectories of human access to the Arctic, Nature Climate Change, 1, 156-160, doi:10.1038/NCLIMATE1120, 2011.

Stroeve, J. C., Kattsov, V., Barrett, A. P., Serreze, M. C., Pavlova, T., Holland, M. M., and Meier, W. N: Trends in Arctic sea ice extent from CMIP5, CMIP3 and observations, Geophys. Res. Lett., 39, doi:10.1029/2012GL052676, 2012a.

Stroeve, J. C., Serreze, M. C., Holland, M. M., Kay, J. E., Maslanik, J., and Barrett, A. P.: The Arctic's rapidly shrinking sea ice cover: a research synthesis, Climatic Change, 110, 1005-1027, doi:10.1007/s10584-011-0101-1, 2012b.

Winebrake, J., Corbett, J., Green, E., Lauer, A., and Eyring, V.: Mitigating the Health Impacts of Pollution from Oceangoing Shipping: An Assessment of Low-Sulfur Fuel Mandates, Environ. Sci. Technol., 43, 4776-4782, doi:10.1021/es803224q, 2009. 